\title{
Improvement of biological recultivation technology of disturbed solid of oil, gas and condensate field
}

\author{
Gaevaya E.V. \\ Department of technosphere safety of \\ FSBEI of Higher Education of «TUI» \\ FSBEI of Higher Education «Tyumen industrial university», \\ Tyumen, Russia \\ e-mail: ele-gaevaya@ya.ru \\ Skipin L.N. \\ Department of technosphere safety of \\ FSBEI of Higher Education of «TUI» \\ FSBEI of Higher Education «Tyumen industrial university», \\ Tyumen, Russia
}

\begin{abstract}
The article considers development of the technology of recovering disturbed soils intended for nature protection purposes on the territory of Bovanenkovskiy oil, gas and condensate field of Yamal peninsula. In the course of operation, blend composition and consumption rates of seed material were selected, technologies on recultivation sites were established. To perform the research and developmental works on the establishment of the biological recultivation technologies the composition of mixed grass crop, consisting of 5 types of graminaceous plants (poa pratensis, bromopsis inermis, festuca pratensis, festuca rubra, phleum pratense), was developed. Based on the results of establishing technologies on the sites of recultivation, the quality of reclamation works was controlled. It was revealed that the most efficient technology of recultivation of disturbed soils in conditions of Yamal tundra is «Meadow formation» technology. Optimal norms of seeds of perennial grasses are $100-150 \mathrm{~kg} / \mathrm{ha}$ and those of mineral fertilizer (ammonium nitrate phosphate fertilizer) $-150 \mathrm{~kg} / \mathrm{ha}$. Following the results of establishing the technologies «Torfomat» and «Recultivite», it was determined that the most promising technology is «Torfomat», whereas «Recultivite» is the least promising.
\end{abstract}

Keywords-biological recultivation; disturbed soils; oil; gas and condensate field

\section{INTRODUCTION}

The territory of recultivation works is located within Bovanenkovskiy oils, gas and condensate fields of Yamal peninsula and includes sites of location of abandoned and suspended exploration wells, mastering and development of which was finished in the 70-90-s of the previous century [13].

Disturbed sites on the territory, adjoining the exploration wells, are characterized by different degrees of man-caused damages of soil and vegetation cover. The operational territory is represented mainly by sites littered by fragments of metal

\author{
Zakharova E.V. \\ Department of technosphere safety of \\ FSBEI of Higher Education of «TUI» \\ FSBEI of Higher Education «Tyumen industrial university», \\ Tyumen, Russia
}

\section{Galyamov A.A.}

Department of technosphere safety of FSBEI of Higher Education of «TUI»

FSBEI of Higher Education «Tyumen industrial university», Tyumen, Russia

structures from drilling equipment or remains of chemical reagents, used for the development of exploration wells [4, 5].

The sites of establishment of sample plots mainly have tundra sedentary and gley and peaty soils with predominant loamy mechanical content $[6,7]$. In the majority of cases, there is transformation of the higher level of soils and the presence of inclusions of man-induced origination in the soil column $[8,9]$.

Vegetation within the plots of sample recultivation was formed by typical grass and mossy tundras in combination with willow tree communities. On the plots of impoundment, separate associations of hydrogenic sedge and cotton grass plants in complex with sphagnum mosses are presented. On man-induced transformed plots, the vegetation cover is represented mainly my perennial crops which form rather developed and dense sward [10].

\section{MATERIALS AND METHODS}

Nowadays the territory of Yamal-Nenets autonomous district lacks recognized varieties of grass, adopted to the growing in tundra zones and also there are no nursery-gardens for growing typical tundra gramineous forage plants (Arctophila fulva, Arctagrostis latifolia, Calamagrostis langsdorfii, Dupontia fisheri, Elymus sibiricus) to get the seeds for carrying out biological recultivation works. Based on results of previously accomplished works, the personnel of the experimental station recommended the most perspective types of grazing perennial grass: poa pratensis, bromopsis inermis, festuca pratensis, festuca rubra, phleum pratense [11, 12] .

To carry out scientific and development works on the establishment of technologies of biological recultivation, the composition of mixed grass crop, consisting of 5 types of gramineous cultivated plants, was developed, the image of which is provided in table 1 . 
Table 1. Variants of mixed grass crop of gramineous cultivated plants seeds

\begin{tabular}{|c|c|}
\hline Mixed grass crop & Ratio in mixed grass crop, $\%$ \\
\hline 1 & 2 \\
\hline Poa pratensis & 8 \\
\hline Bromis inermis & 23 \\
\hline Festuca pratensis & 23 \\
\hline Festuca rubra & 23 \\
\hline Phleum pratense & 23 \\
\hline
\end{tabular}

The applied types of plants included into the mixed grass crops are able to grow on the poor soil substrates; they are resistible to inundation and are able to remain in grass up to 15 years. They are widely used during the creation of cultivated pasture and are proper forage plants.

For carrying out works on the evaluation of the efficiency, 5 technologies were used: «Grassing», «Biomat», «Torfomat», «Recultivite», approbation of which took place on the sites with different types of disturbances arisen as a result of human-induced disturbance (table 2).

Table 2. List of biological recultivation technologies

\begin{tabular}{|c|c|c|}
\hline № & Biological recultivation technologies & $\begin{array}{l}\text { Open-cast } \\
\text { mine №4 }\end{array}$ \\
\hline 1 & Biomat & + \\
\hline 1.1 & $\begin{array}{l}\text { Rate of mixed grass crop }(110 \mathrm{~kg} / \mathrm{ha})+\text { different dose } \\
\text { of ANP fertilizer }\end{array}$ & + \\
\hline 1.2 & $\begin{array}{l}\text { Rate of mixed grass crop }(110 \mathrm{~kg} / \mathrm{ha})+\text { different dose } \\
\text { of ANP fertilizer }-\mathrm{kg} / \mathrm{ha}+\text { sodium humate }(0.05 \%)\end{array}$ & + \\
\hline 1.3 & $\begin{array}{l}\text { Rate of mixed grass crop }(110 \mathrm{~kg} / \mathrm{ha})+\text { sodium } \\
\text { humate }(0.05 \%)\end{array}$ & + \\
\hline 2 & $\begin{array}{l}\text { «Torfomat» Different rate of mixed grass crop + } \\
\text { complex mineral fertilizer «ANP fertilizer» }\end{array}$ & + \\
\hline 3 & «Granilated sowing» & + \\
\hline 3.1 & Different rate of mixed grass crop & + \\
\hline 3.2 & $\begin{array}{l}\text { Different rate of mixed grass crop }+ \text { complex mineral } \\
\text { ANP fertilizer }\end{array}$ & + \\
\hline 4 & $\begin{array}{l}\text { «Recultivite» Different rate of mixed grass crop }+ \\
\text { complex mineral ANP fertilizer }\end{array}$ & + \\
\hline 5 & Grassing & + \\
\hline 5.1 & $\begin{array}{l}\text { Different rate of mixed grass crop }+ \text { complex mineral } \\
\text { ANP fertilizer }\end{array}$ & + \\
\hline 5.2 & $\begin{array}{l}\text { Without mineral fertilizer (different rate of mixed } \\
\text { grass crop) - Control }\end{array}$ & + \\
\hline 5.3 & Different rate of mineral fertilizers «ANP fertilizer» & + \\
\hline 5.4 & Humic formulation «Rostok» & + \\
\hline 5.5 & Sodium humate & + \\
\hline
\end{tabular}

\section{«Biomat» technology}

«Biomat» technology is applied for the first time in conditions of Yamal tundra.

Nowadays biomats are used during the recovery of the soil-ground and vegetable layer on the disturbed plots and also in strengthening and protection of the surface from erosion and formation of ravines. The objects of biomat application are pipeline routes, slopes, slants of mounds and automobile roads.

«Biomat» consists of biodegraded flax bunting with seeds of perennial grasses and mineral fertilizers. Depending on the climate conditions of districts, inclination and degree of drainage, 5 types and 20 brands of "Biomat" were developed. In the work, «Biomat» of brand BT-CO/130 (2.0), consisting of rolls $650 \mathrm{~g}$ thick, $2 \mathrm{~m}$ wide, $25 \mathrm{~m}$ long, weighing $30-35 \mathrm{~kg}$, was used. Establishment of biomat is carried out manually and fixed with cramps $30 \mathrm{~cm}$ long and is covered with $2-3 \mathrm{~cm}$ sand substrate layer.

\section{Technology «Granulated sowing”}

Granule composition includes sapropel, seeds of perennial grasses and complex mineral fertilizer. The size of applied granules is $1.5^{*} 3 \mathrm{~cm}$. Topicality of use of sapropel as substrate in granule preparation is explained by the fact that it is a good organo-mineral fertilizer, necessary for the efficient growth and development of plant cover on the soils of poor mineral content. By the level of content of nutrient substances, it is close to dung of the cattle or even overcomes it. On average, sapropel contains $1,7 \%$ of the total amount of nitrogen; $0.16 \%$ of the total amount of phosphorus and $23 \%$ of potassium. Sapropel can be applied for all types of soil; it improves mechanical structure, water-absorbing ability and moistureretaining power. It also establishes the favorable subacid and neutral reaction. Introduction of sapropel is expedient on soils that are not enough moistened, on the uplands of relief and slants.

Due to granulation of organic-mineral fertilizers, the complex of inoculum also provides effective use of nutrients by the plants in the area of their concentration.

\section{«Torfomat» technology}

One of efficient ways of solution of the problems connected with the strengthening of slants as well as recovering of territories, damaged by man, is the creation and use of special biomats in practice «Torfomat».

«Torfomat» consists of 2 layers of spunbond, sewed at the distance of $15 \mathrm{~cm}$, where peat substrate is placed in $1-2 \mathrm{~cm}$ layer. Peat-sewing matt consists of rolls with $2 \mathrm{~m}$ width, $10 \mathrm{~m}$ length and 70-80 kg weight. Material is laid on sand surface, seeding is carried out on the surface and then covered with sand ground 2-3 layer.

Technology «Recultivite» - synthetic substitute of humus

«Recultivite» consists of ion-exchange materials. This composition is identical to the humus of natural soils, which contains nutrients.

\section{Technology «Grassing»}

Technology «Grassing» is based on the sowing of seeds of perennial gramineous grasses, adding mineral fertilizers and humus formulations. The method «Grassing» is a traditional method, which has been widely used in the recultivation of disturbed lands in the Far North.

Depending on the type of soil substrate and the type of disturbance, optimal seeding rates, mineral fertilization and 
the effectiveness of humic preparations will be determined in the article.

Technology "grassing» in northern latitudes was tested in the early 90-s on the sandy soils near the shift of Bovanenkovo village. For the study, 24 species of annual and perennial plants, consisting of zoned varieties for northern Canada and Alaska, were used. As a result of the conducted experiments, it was established that only 6 species of plants form the main phytocenosis. In experiments using a planter, the projective cover of soils with sown phytocenosis averaged $60 \%$, and when sowing seeds manually, the projective cover of the soils reached $30 \%$. The existing experience of using this method in the northern latitudes has established the need to search for zoned plant species, developed optimal rates for sowing grasses and mineral fertilizers, as well as the advisability of using growth regulators that ensure effective restoration of disturbed and contaminated lands.

Establishment of the proposed recultivation technologies was carried out according to the developed plan-schemes for each disturbed site. Schemes of variants for establishment of recultivation technologies are presented in Tables 3-8.

Table 3. Scheme of variants of technology establishment

\begin{tabular}{|c|c|c|}
\hline \multicolumn{3}{|c|}{ Torfomat (different rate of mixed grass crop - kg/ha) + ANP fertilizer } \\
$\mathbf{1 5 0} \mathbf{~ k g} / \mathbf{h a}$
\end{tabular}

Table 4. Scheme of variants of technology establishment

\begin{tabular}{|c|c|c|}
\hline \multicolumn{3}{|c|}{ Recultivite (different rate of mixed grass crop - $\mathbf{~ k g / h a ) ~ + ~ A N P ~ f e r t i l i z e r ~}$} \\
$\mathbf{1 5 0 \mathrm { kg } / \mathrm { ha }}$ \\
\hline 100 & 150 & 200 \\
\hline
\end{tabular}

Table 5. Scheme of variants of technology establishment

\begin{tabular}{|c|c|c|c|c|c|c|c|c|}
\hline \multicolumn{3}{|c|}{$\begin{array}{c}\text { Grassing (different } \\
\text { rate of mixed grass } \\
\text { crop - kg/ha) }+ \\
\text { watering with humic } \\
\text { preparation } \\
\text { «ostok» }(0.001 \%)\end{array}$} & \multicolumn{3}{|c|}{$\begin{array}{l}\text { Grassing (different } \\
\text { rate of mixed grass } \\
\text { crop - } \mathrm{kg} / \mathrm{ha} \text { ) }\end{array}$} & \multicolumn{3}{|c|}{$\begin{array}{l}\text { Grassing (different } \\
\text { rate of mixed grass } \\
\text { crop - kg/ha) ANP } \\
\text { fertilizer }(150 \mathrm{~kg} / \mathrm{ha})\end{array}$} \\
\hline 100 & 150 & 200 & 100 & 150 & 200 & 100 & 150 & 200 \\
\hline
\end{tabular}

Table 6. Scheme of variants of technology variants

\begin{tabular}{|c|c|c|c|c|}
\hline $\begin{array}{c}\text { Grassing (rate of mixed grass crop - 100 } \\
\text { kg/ha) + different rate of mixed grass } \\
\text { crop - kg/ha }\end{array}$ & $\begin{array}{c}\text { Grassing (rate of mixed } \\
\text { grass crop - 200 kg/ha) + } \\
\text { sodium humate }(\mathbf{0 . 0 5 \% )}\end{array}$ \\
\hline $\begin{array}{c}0 \\
\text { control }\end{array}$ & 100 & 150 & 200 & \\
\hline
\end{tabular}

Table 7. Scheme of variants of technology variants

\begin{tabular}{|c|c|c|}
\hline $\begin{array}{c}\text { Biomat } \\
\text { Rate of mixed grass crop (110 } \\
\mathrm{kg} / \mathrm{ha})+ \text { different dose of } \\
\text { adding ANP fertilizer- } \mathrm{kg} / \mathrm{ha}\end{array}$ & $\begin{array}{c}\text { Biomat } \\
\text { Rate of mixed grass } \\
\text { crop }(110 \mathrm{~kg} / \mathrm{ha})+ \\
\text { different dose of } \\
\text { adding ANP } \\
\text { fertilizer- } \mathrm{kg} / \mathrm{ha} \\
\text { + sodium humate }\end{array}$ & $\begin{array}{c}\text { Biomat } \\
\text { Rate of mixed } \\
\text { grass crop } \\
(110 \mathrm{~kg} / \mathrm{ha}) \\
+ \text { sodium } \\
\text { humate } \\
(0.05 \%)\end{array}$ \\
\hline
\end{tabular}

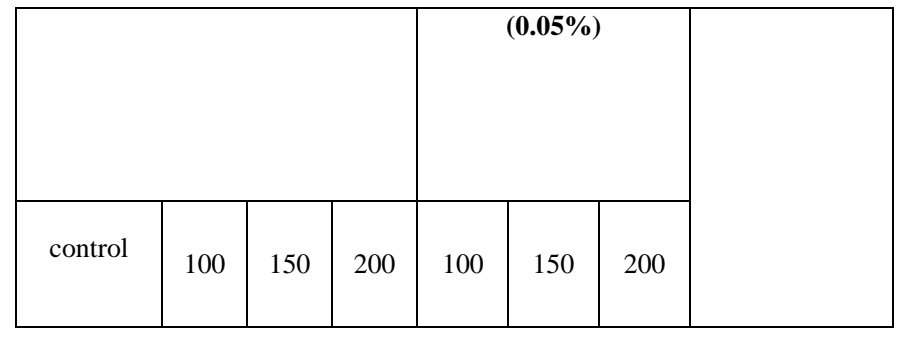

Table 8. Scheme of variants of technology variants

\begin{tabular}{|c|c|c|c|}
\hline \multicolumn{3}{|c|}{ Granulated sowing } \\
\hline \multicolumn{2}{|c|}{$\begin{array}{c}\text { Rate per 1 ha: } \\
\text { 650 kg - sapropel }\end{array}$} & \multicolumn{2}{|c|}{$\begin{array}{c}\text { Rate per 1 ha: } \\
\mathbf{6 5 0} \mathbf{~ k g} \text { - sapropel, } \\
\mathbf{1 5 0} \mathbf{~ k g} \text { - ANP fertilizer }\end{array}$} \\
\hline $\begin{array}{c}100 \mathrm{~kg} \text { - mixed } \\
\text { grass crop }\end{array}$ & $\begin{array}{c}150 \mathrm{~kg}- \\
\text { mixed grass } \\
\text { crop }\end{array}$ & $\begin{array}{c}100 \mathrm{~kg} \text { - mixed } \\
\text { grass crop }\end{array}$ & $\begin{array}{c}150 \mathrm{~kg}-\text { mixed } \\
\text { grass crop }\end{array}$ \\
\hline
\end{tabular}

On the territory of Bavanenkovskoe field, biological recultivation of the site was organised. An object of pioneering development and modern arrangement of the gas industry with different types of violations was selected for such site. The site is located on the territory of the Bovanenkovskoye field: the mined quarry of mineral soil No. 4.

Quarry of mineral soil № 4

Location: Tyumen Region, Yamal-Nenets Autonomous District, Yamal District. The pilot site is located $13 \mathrm{~km}$ to the northeast relative to the Industrial Base GP-1 of the Bovanenkovskoye oil and gas field.

Type of disturbance: barrow pit of mineral soil.

Forms of mechanical disturbances: destruction and burial of soils, negative and positive forms of relief.

Degree of destruction: extremely strong, disturbance of soil and vegetation cover by $80-90 \%$, replacement of initial substrates with man-induced soils, violation of hydrological and permafrost processes.

Cluttering of the site: not cluttered up.

Presence of contaminated sites: not visually detected.

The degree of development and tendency in the processes of transformation are severe degradation and weak recovery, active process of restructuring; combination of zones of sustainable degradation with recovery zones and replacement of tundra natural-territorial complexes.

Exogenous processes: erosion, deflation

Assessment of the state of vegetation cover:

Before carrying out research works: the vegetative community is oppressed, consisting of weed vegetation; the projective covering of soils is no more than $5 \%$.

After carrying out research works, the vegetative community became viable, consisting of cultivated gramineous plants; projective covering of soils ranges from 60 to $95 \%$.

\section{RESULTS}

Quality control of the establishment and efficiency of biological recultivation technologies on sites was carried out 
during the summer vegetation period during the tillering phase of sown herbage.

The technology «Grassing» was established on sites using various rates of mixed grass crops, mineral fertilizers (ANP fertilizer), humic preparations «Humate of sodium», «Rostok». In the course of work, 5 different variants of the proposed technology were tested on the sites of different degree of disturbance.

The soil substrate for the establishment of technologies for biological recultivation was primitive sandy disturbed soils (quarry of mineral soil No. 4).

According to the proposed variants, the results were analyzed and the effectiveness of their use for recultivation of disturbed lands in the Bovanenkovskoye field was evaluated.

The determining criterion for the effectiveness of the recultivation technology applied in the plots is the indicator of the projective cover of plants, the height of the over-ground part of the shoots, and the mass of the vegetative over-ground shoots (Table 9, 10, 11).

Table 9. Recover of disturbed lands using technology «Grassing»

\begin{tabular}{|c|c|c|c|c|c|c|}
\hline \multirow{3}{*}{ Technology } & \multicolumn{6}{|c|}{ «Grassing» } \\
\hline & \multicolumn{3}{|c|}{$\begin{array}{l}\text { Different rate of mixed } \\
\text { grass crop kg/ha+ } \\
\text { «Rostok» }\end{array}$} & \multicolumn{3}{|c|}{$\begin{array}{l}\text { Different rate of } \\
\text { grass crop }(\mathrm{kg} / \mathrm{ha})\end{array}$} \\
\hline & 100 & 150 & 200 & 100 & 150 & 200 \\
\hline $\begin{array}{l}\text { Projective } \\
\text { coverage, } \%\end{array}$ & 20 & 70 & 45 & 60 & 50 & 45 \\
\hline $\begin{array}{l}\text { Phenological } \\
\text { phase }\end{array}$ & \multicolumn{6}{|c|}{ Vegetation (stooling and development of rosette) } \\
\hline $\begin{array}{l}\text { Zoetic state } \\
\text { of plants }\end{array}$ & \multicolumn{6}{|c|}{$\begin{array}{l}\text { Viable spices with well developed over-ground and } \\
\text { underground shoots }\end{array}$} \\
\hline $\begin{array}{l}\text { Height of } \\
\text { over-ground } \\
\text { shoots, cm }\end{array}$ & 7.3 & 11.5 & 7 & 10 & 7 & 8.1 \\
\hline $\begin{array}{l}\text { Weight of } \\
\text { vegetative } \\
\text { over-ground } \\
\text { shoots, g/m }{ }^{2} \\
\text { (wet weight) }\end{array}$ & 35 & 60 & 45 & 53 & 58 & 62 \\
\hline $\begin{array}{l}\text { Degree of } \\
\text { occupation of } \\
\text { site with } \\
\text { native } \\
\text { vegetation, \% }\end{array}$ & 0 & 0 & 0 & 0 & 0 & 0 \\
\hline
\end{tabular}

Table 10. Recover of disturbed lands using technology «Grassing»

\begin{tabular}{|l|l|l|l|}
\hline \multirow{2}{*}{ Technology } & \multicolumn{2}{|c|}{ «Grassing» } \\
\cline { 2 - 4 } & $\begin{array}{l}\text { Different rate of mixed grass crop+ ANP } \\
\text { fertilizer (150 kg/ha) }\end{array}$ \\
\cline { 2 - 3 } & $\mathbf{1 0 0}$ & $\mathbf{1 5 0}$ & $\mathbf{2 0 0}$ \\
\hline Projective coverage, \% & 60 & 70 & 75 \\
\hline Phenological phase & $\begin{array}{l}\text { Vegetation (stooling and development of } \\
\text { rosette) }\end{array}$ \\
\hline Zoetic state of plants & $\begin{array}{l}\text { Viable spices with well developed over- } \\
\text { ground and underground shoots }\end{array}$ \\
\hline
\end{tabular}

\begin{tabular}{|l|l|l|l|}
\hline \multirow{2}{*}{ Technology } & \multicolumn{3}{|c|}{ «Grassing» } \\
\cline { 2 - 4 } & \multicolumn{2}{|c|}{ Different rate of mixed grass crop+ ANP } \\
fertilizer (150 kg/ha)
\end{tabular}

Table 11. Recover of the disturbed soils using technologies «Grassing»

\begin{tabular}{|c|c|c|c|c|c|}
\hline \multirow{3}{*}{ Technologies } & \multicolumn{5}{|c|}{ «Grassing» } \\
\hline & \multicolumn{4}{|c|}{$\begin{array}{l}\text { Mixed grass crop - } 100 \mathrm{~kg} / \mathrm{ha} \text {, } \\
\text { Different rate of } \mathrm{ANP} \text { fertilizer, } \\
\mathrm{kg} / \mathrm{ha}\end{array}$} & \multirow[t]{2}{*}{$\begin{array}{l}\text { Mixed } \\
\text { grass crop - } \\
200 \mathrm{~kg} / \mathrm{ha}+ \\
\text { sodium } \\
\text { humate } \\
\end{array}$} \\
\hline & 0 & 100 & 150 & 200 & \\
\hline $\begin{array}{l}\text { Projective } \\
\text { coverage, } \%\end{array}$ & 30 & 70 & 80 & 90 & 30 \\
\hline $\begin{array}{l}\text { Phenological } \\
\text { phase }\end{array}$ & \multicolumn{5}{|c|}{ Vegetation (stooling and development of rosette) } \\
\hline $\begin{array}{l}\text { Zoetic state of } \\
\text { plants }\end{array}$ & \multicolumn{5}{|c|}{$\begin{array}{l}\text { Viable spices with well developed over-ground and } \\
\text { underground shoots }\end{array}$} \\
\hline $\begin{array}{l}\text { Height of over- } \\
\text { ground shoots, } \\
\mathrm{cm}\end{array}$ & 7 & 18.3 & 14.0 & 19.0 & 12.6 \\
\hline 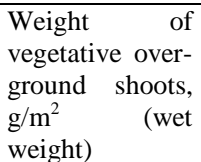 & 60 & 480 & 604 & 884 & 20 \\
\hline $\begin{array}{l}\text { Degree of } \\
\text { occupation of } \\
\text { site with native } \\
\text { vegetation, \% }\end{array}$ & 5 & 5 & 5 & 5 & 5 \\
\hline
\end{tabular}

According to the results of the measurements of the vegetation cover, the most effective result is established on the sandy substrates - the rate of seeds of perennial grasses and mineral fertilizers is $150 \mathrm{~kg} / \mathrm{ha}$. The projective coverage of soils on the sites is more than $70 \%$, the height of the aboveground shoots is more than $20 \mathrm{~cm}$, the mass of above-ground shoots is more than $400 \mathrm{~g} / \mathrm{m} 2$ of wet weight.

In the experiments with a different rate of sowing seeds of perennial plants and without application of mineral fertilizers (control), a rare grass stand is observed, the projective cover of soils is from 30 to $60 \%$, the height of the above-ground shoots is $7 \mathrm{~cm}$, and the mass of above-ground shoots is $60 \mathrm{~g} /$ $\mathrm{m} 2$.

Tests using humic substances (humate of sodium, «Rostok») were established. As a result of examining these sites, slow growth of plants was noticed, uneven appearance of sprouts, projective cover of soils made up from 20 to $90 \%$.

The results of the performed studies allow us to conclude that the optimum rates of consumption of the complex mineral fertilizer (ANP fertilizer) are $150 \mathrm{~kg} / \mathrm{ha}$ per the disturbed sandy soils, the seeds of perennial grasses on sandy soils of $150 \mathrm{~kg} / \mathrm{kg}$. 
Two technologies «Peat», «Recultivite» were established with the use of various mineral fertilizers of the ANP fertilizer $(750 \mathrm{~kg} / \mathrm{ha})$ and various mixed grass crops $(100,150,200$ $\mathrm{kg} / \mathrm{ha})$. The results of the research are presented in Table 12.

Table 12. Recover of disturbed soils using technologies «Torfomat», «Recultivite»

\begin{tabular}{|c|c|c|}
\hline Technology & $\begin{array}{l}\text { «Torfomat» } \\
\text { Mixed grass crop } \\
(100,150,200 \mathrm{~kg} / \mathrm{ha}) \\
+ \\
\text { ANP fertilizer } 150 \\
\text { kg/ha }\end{array}$ & $\begin{array}{l}\text { «Recultivite» } \\
\text { Mixed grass crop } \\
(100,150,200 \mathrm{~kg} / \mathrm{ha}) \\
+ \\
\text { ANP fertilizer } 150 \\
\mathrm{~kg} / \mathrm{ha}\end{array}$ \\
\hline Projective coverage, $\%$ & 85 & 70 \\
\hline Phenological phase & \multicolumn{2}{|c|}{ Vegetation (stooling and development of rosette) } \\
\hline Zoetic state of plants & \multicolumn{2}{|c|}{$\begin{array}{l}\text { Viable spices with well developed over-ground } \\
\text { and underground shoots }\end{array}$} \\
\hline $\begin{array}{l}\text { Height of over-ground } \\
\text { shoots, cm }\end{array}$ & 25 & 17 \\
\hline $\begin{array}{l}\text { Weight of vegetative } \\
\text { over-ground shoots, } \\
\mathrm{g} / \mathrm{m}^{2} \text { (wet weight) }\end{array}$ & 444 & 100.0 \\
\hline $\begin{array}{l}\text { Degree of occupation } \\
\text { of recultivated site } \\
\text { with native vegetation, } \\
\%\end{array}$ & 0 & 0 \\
\hline
\end{tabular}

According to the results of measurements of the vegetative cover of the «Torfomat» technology, it is established that when seeds are introduced into the peat-stitched material at the rate of $100,150,200 \mathrm{~kg} / \mathrm{ha}$, there is an intensive recovery of the vegetation cover. Projective coverage is $85 \%$, the height of the above-ground shoots reaches $25 \mathrm{~cm}$ and the mass of above-ground shoots is $450 \mathrm{~g} \mathrm{~m}^{2}$.

According to the results of the «Recultivite» technology, the projected coverage of soils is about $70 \%$, with low heights $(17 \mathrm{~cm})$ and the mass of above-ground shoots $\left(100 \mathrm{~g} / \mathrm{m}^{2}\right.$ of wet weight). In general, the proven technology is inefficient and inappropriate for the recovery of disturbed lands.

Comparative analysis of the results obtained from the establishment of two technologies allows us to conclude that growth and development are higher in the case of the use of the technology «Torfomat». The use of the technology «Recultivite» does not have a significant effect on the growth and development of plants.

The «Biomat» technology was established on the quarry of mineral soil No. 4. A series of experiments on the approbation of this technology included options with the use of mineral fertilizers (ANP fertilizer), humic preparations (sodium humate) with a constant rate of seeds of perennials - 110 $\mathrm{kg} / \mathrm{ha}$. The results of observations are presented in Table 13 .
Table 13. Recover of disturbed soils using technology «Biomat»

\begin{tabular}{|c|c|c|c|c|}
\hline \multirow[b]{2}{*}{ Technology } & \multicolumn{4}{|c|}{ «Biomat» } \\
\hline & $\begin{array}{l}\text { Contr } \\
\text { ol }\end{array}$ & $\begin{array}{l}\text { Sodi } \\
\text { um } \\
\text { hum } \\
\text { ate }\end{array}$ & $\begin{array}{l}\text { Differe } \\
\text { nt rate } \\
\text { of ANP } \\
\text { fertiliz } \\
\text { er - } \\
100 \\
\mathrm{~kg} / \mathrm{ha},- \\
150 \\
\mathrm{~kg} / \mathrm{ha}, \\
200 \\
\mathrm{~kg} / \mathrm{ha}\end{array}$ & $\begin{array}{l}\text { Different } \\
\text { rate of } \\
\text { ANP } \\
\text { fertilizer } \\
\text { +sodium } \\
\text { humate } \\
\text { - } 100 \\
\mathrm{~kg} / \mathrm{ha} \\
,-150 \\
\mathrm{~kg} / \mathrm{ha}, \\
200 \mathrm{~kg} / \mathrm{ha}\end{array}$ \\
\hline Projective coverage, $\%$ & 70 & 35 & 95 & 90 \\
\hline Phenological phase & \multicolumn{4}{|c|}{$\begin{array}{l}\text { Vegetation (stooling and development of } \\
\text { rosette) }\end{array}$} \\
\hline Zoetic state of plants & \multicolumn{4}{|c|}{$\begin{array}{l}\text { Viable spices with well developed over- } \\
\text { ground and underground shoots }\end{array}$} \\
\hline $\begin{array}{l}\text { Height of over-ground } \\
\text { shoots, cm }\end{array}$ & 14.3 & 17.5 & 29.6 & 28 \\
\hline $\begin{array}{l}\text { Weight of vegetative over- } \\
\text { ground shoots, } \mathrm{g} / \mathrm{m}^{2} \text { (wet } \\
\text { weight) }\end{array}$ & 118 & 121 & 1280 & 1180 \\
\hline $\begin{array}{l}\text { Degree of occupation of } \\
\text { site with native vegetation, } \\
\%\end{array}$ & 0 & 0 & 0 & 0 \\
\hline
\end{tabular}

In a series of experiments on the restoration of disturbed areas using non-woven fabric «Biomat» and various rates of ANP fertilizer, the most revealing are the results, where the projective cover of soils reaches $95 \%$, the height of the aboveground shoots is up to $30 \mathrm{~cm}$, the vegetative over-ground mass is about $1.5 \mathrm{~kg} / \mathrm{m}^{2}$. Sufficiently high values of the studied parameters were established in variants with ANP fertilizer $(100,150,200 \mathrm{~kg} / \mathrm{ha})$. Thus, it can be concluded that the introduction of ANP fertilizer favorably affects the development of plants.

In the control series of experiments of the «Biomat» technology without the application of mineral fertilizers, the maximum projective coverage is $70 \%$, the mass of the aboveground shoots is $118 \mathrm{~g} / \mathrm{m}^{2}$.

In a series of experiments with usage of humic substances, less representative results were obtained, a projective cover of soils is $35 \%$ on average, mass of above-ground shoots is about $121 / \mathrm{m}^{2}$ of wet mass. The results of studies on the use of humic drugs indicate their relatively low effectiveness.

Thus, we can conclude that the most effective in this series of experiments are experiments on establishment of trial sites «Biomat» based on the introduction of a complex mineral fertilizer - ANP fertilizer without using humic preparations.

Experimental studies on the effectiveness of the application of the technology «Granulated sowing» were conducted on sites. The results of the studies are presented in the Table 14.

Scientific research on the establishment of technologies, provided for the introduction of two options for the composition of granules, was conducted:

- seeds of perennial grasses and sapropel (control); 
- seeds of perennial grasses, sapropel in combination with the ANP fertilizer.

The flow rate of the seed material was 100 and $150 \mathrm{~kg} / \mathrm{ha}$, respectively, in two series of experiments, the rate of application of ANP fertilizer was $150 \mathrm{~kg} / \mathrm{ha}$.

Table 14. Recovery of disturbed soils using the technology «Granulated sowing»

\begin{tabular}{|c|c|c|c|c|}
\hline \multirow[b]{2}{*}{ Technology } & \multicolumn{4}{|c|}{ «Granulated sowing» } \\
\hline & $\begin{array}{l}\text { Mixed } \\
\text { grass crop } \\
- \\
100 \mathrm{~kg}\end{array}$ & $\begin{array}{l}\text { Mixed } \\
\text { grass crop } \\
-150 \mathrm{~kg}\end{array}$ & $\begin{array}{l}\text { Mixed } \\
\text { grass } \\
\text { crop - } \\
100 \mathrm{~kg} \\
\text { fertilizer } \\
-\quad 150 \\
\text { kg/ha }\end{array}$ & $\begin{array}{l}\text { Mixed } \\
\text { grass crop } \\
-150 \mathrm{~kg} \text {, } \\
\text { ANP } \\
\text { fertilizer } \\
-\quad 150 \\
\mathrm{~kg} / \mathrm{ha}\end{array}$ \\
\hline $\begin{array}{l}\text { Projective } \\
\text { coverage, } \%\end{array}$ & 70 & 75 & 80 & 90 \\
\hline $\begin{array}{l}\text { Phenological } \\
\text { phase }\end{array}$ & \multicolumn{4}{|c|}{ Vegetation (stooling and development of rosette) } \\
\hline $\begin{array}{l}\text { Zoetic state of } \\
\text { plants }\end{array}$ & \multicolumn{4}{|c|}{$\begin{array}{l}\text { Viable spices with well developed over-ground and } \\
\text { underground shoots and root system }\end{array}$} \\
\hline $\begin{array}{l}\text { Height of over- } \\
\text { ground shoots, } \\
\mathrm{cm}\end{array}$ & 13 & 14.8 & 12.3 & 19.9 \\
\hline $\begin{array}{l}\text { Weight of } \\
\text { vegetative over- } \\
\text { ground shoots, } \\
\mathrm{g} / \mathrm{m}^{2} \\
\text { weight) }\end{array}$ & 305 & 316 & 313 & 323 \\
\hline $\begin{array}{l}\text { Degree of } \\
\text { occupation of } \\
\text { site with native } \\
\text { vegetation, } \%\end{array}$ & 0 & 0 & 0 & 0 \\
\hline
\end{tabular}

Based on the results of the studies, it was established that in each series of experiments, at various flow rates of the seed material, both in the control and in the complex with the ANP fertilizer, the plants develop intensively, as evidenced by the high values of the projective coverage of $70-90 \%$ and the mass of the above-ground shoots of $112-323 \mathrm{~g} / \mathrm{m}^{2}$. A distinctive feature of the use of this technology is a pronounced uniform growth and development of plants, which may be due to certain features of the germination of seeds from granules.

Proceeding from the fact that there are no significant differences in the studied indicators of the vegetation cover on the observation platforms, it can be concluded that seeds develop mainly due to the substances coming from the very substance of the granules - sapropel. To ensure the effective growth and development of plants, it is necessary to use a complex mineral fertilizer in the granules to account for the disturbed erosion-hazardous areas of $150 \mathrm{~kg} / \mathrm{ha}$, on sandy soils - $100 \mathrm{~kg} / \mathrm{ha}$, and mixed grass crops of perennial grasses $100-150 \mathrm{~kg} / \mathrm{ha}$.

\section{CONCLUSION}

Thus, according to the results of the carried out scientific and research works of establishment of biological recultivation technologies on the sites, the following conclusions can be made. The most effective technologies for the recultivation of disturbed lands in the Yamal tundra are: «Grassing», «Biomat», «Torfomat» and «Granular sowing». Technology «Grassing» is effective for the recovery of disturbed lands. Optimum rates of seeds of perennial grasses are 100-150 $\mathrm{kg} / \mathrm{ha}$, and that of the mineral fertilizer (ANP fertilizer) -150 $\mathrm{kg} / \mathrm{ha}$.

On the sites approved by the «Biomat» technology, the best indicators for the development of vegetation cover were obtained with the application of a complex mineral fertilizer at a rate of $150 \mathrm{~kg} / \mathrm{ha}$ of the ANP fertilizer and a seed rate of more than $100 \mathrm{~kg} / \mathrm{ha}$ in the biomat bunting. As a result of the establishment of technologies «Torfomat» and «Recultivite», it was found out that the most promising technology is «Torfomat», and the least - «Recultivite».

On the experimental sites, recultivated by the «Granular sowing» technology, the restoration of the vegetative cover actively takes place on the sites with different variants of the application of seeds of grasses and mineral fertilizers. To ensure the effective growth and development of plants, it is necessary to use a complex mineral fertilizer in the composition of granules on the sandy soils - $100 \mathrm{~kg} / \mathrm{ha}$, and mixed grass crops of perennial grasses $-100-150 \mathrm{~kg} / \mathrm{ha}$.

The proposed mixed crass crop for the establishment of technologies can be recommended in the future for carrying out technologies of biological recultivation.

\section{BIBLIOGRAPHY}

[1] O.M. Ermilov, G.I. Griva, V.I., Moskvin The impact of gas industry facilities on northern ecosystems and the ecological stability of geotechnical complexes in the permafrost zone, Novosibirsk: Publishing house: SB RAS, 2002, p. 148.

[2] A.A. Galyamov, E.V. Gayevaya, E.V. Zakharova, "Biological recultivation of agricultural lands (reindeer pastures) on the Yamal peninsula", Bulletin of the Krasnoyarsk State Agrarian University, №10, pp. 17-22, 2015.

[3] A.A. Galyamov, E.V. Gayevaya, E.V. Zakharova, "Ecological problems of restoration of disturbed lands on the Yamal peninsula", Bulletin of the Krasnoyarsk State Agrarian University, №11, pp.16-21, 2015.

[4] N.P. Solntseva, Oil production and geochemistry of natural landscapes, Moscow: Publishing house: MGU, 1998, p. 376.

[5] O.I. Sumina, Man-induced impact on tundra ecosystems and recultivation of disturbed territories, St. Petersburg, Publishing House of St. Petersburg State University, 1992, p. 42.

[6] Atlas of the Yamal-Nenets autonomous district, Omsk: FSUE "Omsk Cartographic Factory", 2004, p. 304.

[7] E.G. Nechaeva, "Landscape-geochemical zoning of the West Siberian plain", Geography and natural resources. 1990, pp. 77-83.

[8] D. V. Moskochenko, Biogeochemical features of the landscapes of the Yamal Peninsula and their optimization in connection with oil and gas production: Thesis. St. Petersburg, 1995, p. 24.

[9] V.V. Kozin, Landscape analysis in the oil and gas field: Monograph. Tumen: Publishing house of Tyumen State University, 2007, p. 240.

[10] L N. Dobrinsky, The nature of Yamal, Ekaterinburg: UIF science, 1995 p. 435.

[11] Biological recultivation of disturbed lands in Yamal. Recommendations. Novosibirsk, 1994 p. 47.

[12] Yu. A. Liiverovsky, A.I. Popov, V.V. Smirnov, Recultivation of the natural landscapes of the Far North, disturbed as a result of human activity. Protecting the environment during the development of the permafrost region, M., Science, 1980, pp. 111-115. 